\section{Planting Date and Plant Density Affect Yield of Pungent and Nonpungent Jalapeño Peppers}

\author{
V.M. Russo ${ }^{1}$ \\ U.S.Department of Agriculture, Agricultural Research Service, South Central \\ Agricultural Research Laboratory, P.O. Box 159, Lane, OK 74555
}

Additional index words. Capsicum annuum, culture, pungency, transplants, yield

\begin{abstract}
There is little known about how cultural methods affect yields of nonpungent jalapeño peppers (Capsicum annuum L.). Seedlings of the nonpungent jalapeño peppers 'Pace 103', 'Pace 105', 'Pace 108', 'Dulce', and 'TAM Sweet2', as well as the pungent jalapeño peppers 'Delicias' and 'TAM Jalapeño1', used for comparison, were grown in a greenhouse with either one or two seedlings per cell in transplant trays. Transplanting to the field was in mid-April and mid-June of 2000 and 2001. In-row spacing was $0.46 \mathrm{~m}$ between transplanting sites. Density was varied by placing either one or two seedlings at a transplant site with resultant plant densities of 24,216 or 48,432 plants/ha. Marketable and cull yields, on a per hectare basis, were determined. In both years there were more fruit produced, and higher yields ( $25+\%$ greater), at the higher plant density, especially for the mid-April planting. The exception for the mid-April planting date was 'TAM Jalapeño1', which was not different at the two densities. If the increased income from higher yield can compensate for the cost of producing two seedlings in each transplant tray cell, then this technique should be employed when these types of peppers are used in early plantings.
\end{abstract}

There is an increased demand among American consumers for various ethnic foods (Andrews, 1995), which has contributed to development of value-added products with varying degrees of pungency derived from pepper. Pungency can be adjusted during processing by dilution, or by the use of recently developed nonpungent peppers and with the addition of known amounts of purified capsaicin.

Cultural methods have been shown to affect pungent jalapeño peppers, as for transplanted pungent 'TAM Mild Jalapeño1' and 'Veracruz' peppers, which had higher yields than direct seeded plants, and as in-row spacing increased from 10 to $30 \mathrm{~cm}$ decreased yield (Leskovar and Boales, 1995). In greenhouse studies with 'Jalapa' jalapeño, increasing concentrations of $\mathrm{N}$ and $\mathrm{K}$ caused pod formation and Scoville Heat Units to increase in a quadratic fashion, while dry weight increased linearly (Johnson and Decoteau, 1996). Russo (1996) determined that a mid-July, rather than a mid-April planting, combined with increased fertilizer, improved yield of the one-time harvested pungent jalapeño pepper 'Mitla'.

Competition can affect plant development and yield, and can be manipulated by changing plant density. Yield of various types of peppers has generally increased as in-row plant spacing decreased (Decoteau and Graham, 1994; Jolliffe and Gaye, 1995; Kahn et al., 1997; Motsenbacker, 1996). However, total marketable

\footnotetext{
Received for publication on 4 Apr. 2002. Accepted for publication on 16 July 2002. Mention of a trademark, vendor, or proprietary product does not constitute a guarantee or warranty of the product by the U.S. Dept. of Agriculture and does not imply its approval to the exclusion of other products that may also be suitable.

${ }^{1}$ E-mail address: vrusso-usda@lane-ag.org
}

yield for the pungent jalapeño peppers 'TAM Jalapeño1' and 'Jalapeño M' were not affected by varying in-row plant spacings from 10.2 to $40.6 \mathrm{~cm}$ (Motsenbocker et al., 1997).

Plant density can be increased by using more than one plant per transplant site while keeping the distance between transplant sites constant. For plants from seed sown in October, marketable yield of bell pepper was not affected as number of plants was increased from one to three at each planting site in one location in Florida, but did increase when seed were sown in a like manner in December (Stoffella and Bryan, 1988). Multiple plants within a transplant tray cell could be substituted for single plants in transplant tray cells to increase plant density while maintaining the same inrow spacing.

There is minimal information on the cultural requirements that affect yields of the relatively new types of nonpungent jalapeño peppers. Although there is a long growing season in the southern plains of the United States, the hot summer months have detrimental effects on the yield of solanaceous crops. This is likely due to effects of heat on flower production (Deli and Tiessen, 1969) or retention (Cochran, 1932; Dorland and Went, 1947) rather than to drought since producers have access to supplemental water by irrigation. The objectives of the study were to determine if planting date and plant density in the field affected yield of cultivars of nonpungent and pungent jalapeño peppers. A planting date that would expose plants to periods of prolonged high temperatures was included.

\section{Materials and Methods}

The experiment was conducted on a Bernow fine-loamy, siliceous, thermic Glossic Paleu- dalf soil at Lane, Okla. The planting area was 0.13 ha $(28 \times 50 \mathrm{~m})$. Enough fertilizer was applied preplant, based on results of soil tests, so that nutrient levels in the soil at each planting date were brought to $112 \mathrm{~N}-112 \mathrm{P}-325 \mathrm{~K}$ $\mathrm{kg} \cdot \mathrm{ha}^{-1}$, recommended for peppers in this area (Motes and Roberts, 1994). The source of N was ammonium nitrate; $\mathrm{P}$, phosphoric acid; and $\mathrm{K}$, muriate of potash. Raised beds (20 $\mathrm{cm}$ high and $18 \mathrm{~cm}$ wide) formed from bare soil were oriented east-west on 0.9 -m centers. There were two planting dates in each year, 15 Apr. and 17 June in 2000, and 16 Apr. and 8 June in 2001. Six-week-old greenhousegrown seedlings, with one or two plants in each transplant tray cell, of the nonpungent jalapeño peppers 'Pace 103, 'Pace 105', and 'Pace 108' (Campbell Seeds, Davis, Calif.), 'Dulce' (PetoSeed, Saticoy, Calif.) and 'TAM Sweet2' (Texas Agricultural Experiment Station, Weslaco); and the pungent jalapeño peppers 'Delicias' (PetoSeed, Saticoy, Calif.) and 'TAM Jalapeño1' (Texas Agricultural Experiment Station) were transplanted at each date. The trays in which the transplants were produced were $5.5 \mathrm{~cm}$ deep, $34 \mathrm{~cm}$ wide, and $67.5 \mathrm{~cm}$ long with square cells that were 3.5 $\mathrm{cm}$ on each side (Speedling, American Plant Products, Oklahoma City, Okla.). The pungent pepper cultivars were used for comparison. The responses of the nonpungent cultivars would be less meaningful without a comparison to some known cultivars since information on how these relatively new cultivars respond to differing cultural methods has not been reported.

Transplants were established in the field in a single row with an in-row spacing of $0.46 \mathrm{~m}$ between transplanting sites in plots providing population equivalents of 24,216 (one seedling per transplant site) or 48,432 (two seedlings per transplant site) plants/ha in plots that were 9.2 $\mathrm{m}$ long. Fruit were harvested from 10 plants from a 4.6-m section spanning the center of each plot. Fruit were not harvested from the remaining plants in plots, and there was a single guard row on the north and south that ran the entire length of the treatment plots. Plants received a minimum of $30 \mathrm{~mm}$ of water per week in the form of precipitation or overhead irrigation.

Harvests were made when $\approx 5 \%$ of the number of fruit on plants in a cultivar were red. Fruit were harvested once, which is consistent with industry practices. The cultivars were harvested at different times depending on their maturities. Numbers and yield, on a per hectare basis, of marketable and cull fruit were determined. Fruit were culled if they were undersized, based on the norm for the cultivar provided by the seed supplier, or if they were misshapen. There was minimal damage due to insects or diseases. Average fruit weight was derived mathematically from total weight and total number of fruit produced in plots.

The plots were arranged in a randomized complete-block design in which planting date (2) comprised a split plot. The combination of the factors of cultivar (7) and plant density (2), based on the number of plants at a transplant site (one or two), made up the treatments within blocks. The experiment was conducted 

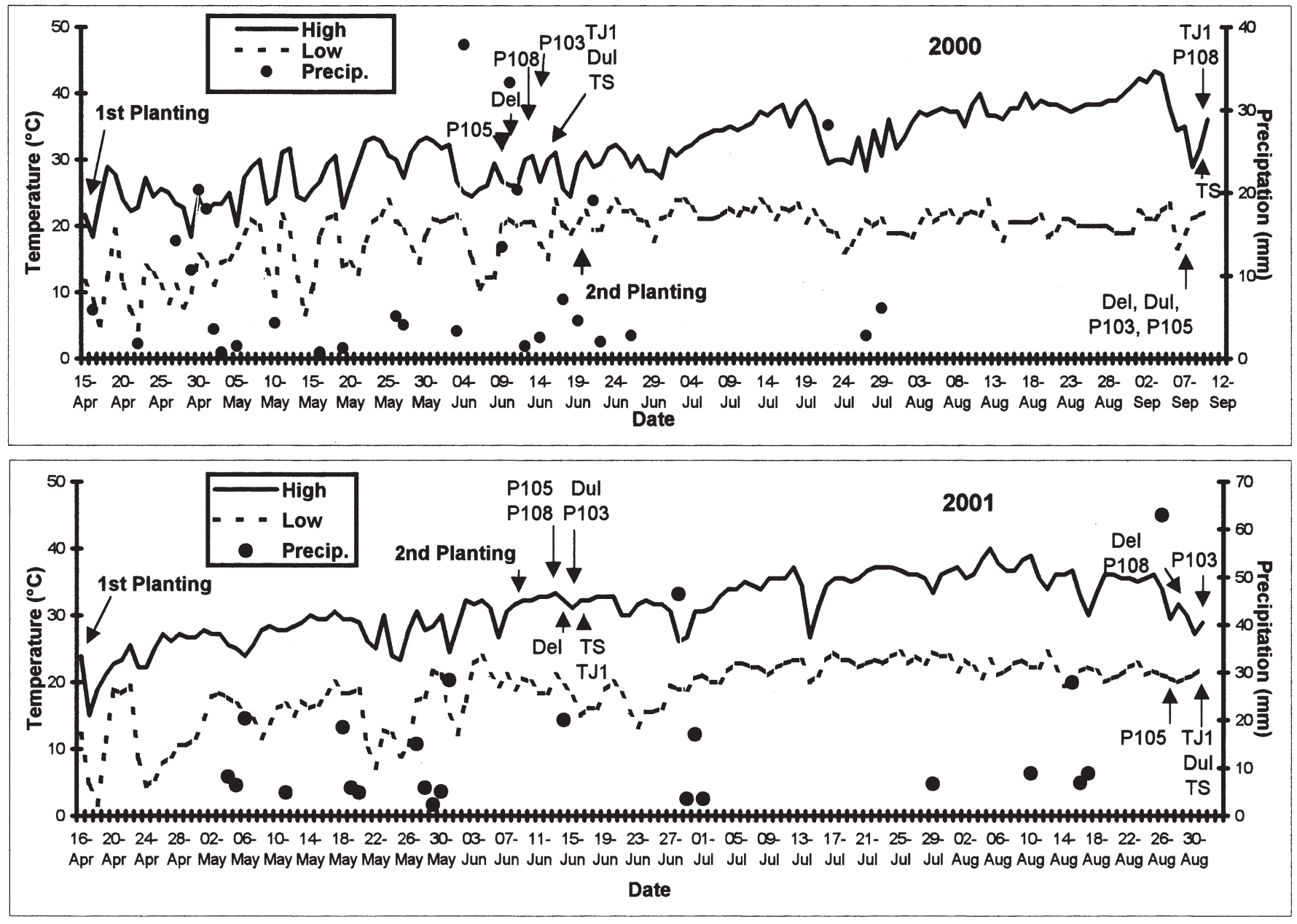

Fig. 1. High and low daily ambient air temperatures and precipitation events (dark circles) for the first and second plantings of pungent and nonpungent jalapeño peppers in 2000 and 2001. Dates of once-over harvests for the cultivars are indicated by arrows associated with abbreviations for the cultivars P103, P105, and P108 = 'Pace103', 'Pace105', and 'Pace108', respectively. Del = 'Delicias', Dul = 'Dulce', TJ1 = 'TAM Jalapeño 1', and TS2 = 'TAM Sweet2'.

in 2000 and 2001 and replicated three times in each year. Year was considered to be a variable due to differences in environmental conditions. The data were analyzed with the general linear models procedures in SAS (SAT Institute, ver. 7, Cary, N.C.). Where appropriate, means were compared using Least Squares Means analysis.

\section{Results and Discussion}

High and low ambient air temperatures and precipitation events are presented in Fig. 1. During the period of the first planting in 2000 there was more precipitation, which was distributed more uniformly, than during the period of the second planting. During the period of the first planting in 2001, the amount of precipitation and the number of events were similar to those for the period of the second planting. However, most of the precipitation events during the first planting occurred during the time of flowering. In both years, there were fewer instances when high temperatures exceeded $32^{\circ} \mathrm{C}$ and low temperatures exceeded $22{ }^{\circ} \mathrm{C}$ in the first planting than in the second planting.

In the first planting of 2000, 'Pace105' was harvested after $84 \mathrm{~d}$; 'Delicias' after 85 d; 'Pace108' after 86 d; 'P103' after 87 d; and

Table 1. Results of ANOVA on marketable and cull yield components of pungent and nonpungent jalapeño peppers cultivars transplanted at two planting dates and two densities in 2000 and 2001.

\begin{tabular}{|c|c|c|c|c|c|c|c|}
\hline \multirow[b]{2}{*}{ Source } & \multirow[b]{2}{*}{$\mathrm{df}$} & \multicolumn{3}{|c|}{ Marketable } & \multicolumn{3}{|c|}{ Cull } \\
\hline & & $\begin{array}{c}\text { No. } \\
\text { (1000s/ha) }\end{array}$ & $\begin{array}{c}\text { Yield } \\
\left(\mathrm{Mg} \cdot \mathrm{ha}^{-1}\right)\end{array}$ & $\begin{array}{c}\text { Avg fruit } \\
\text { Wt }(g)\end{array}$ & $\begin{array}{c}\text { No. } \\
(1000 \mathrm{~s} / \mathrm{ha})\end{array}$ & $\begin{array}{c}\text { Yield } \\
\left(\mathrm{Mg} \cdot \mathrm{ha}^{-1}\right)\end{array}$ & $\begin{array}{c}\text { Avg fruit } \\
\text { Wt }(\mathrm{g})\end{array}$ \\
\hline Model & 63 & & & & & & \\
\hline Error & 104 & & & & & & \\
\hline Corrected total & 167 & & & & & & \\
\hline Year $(\mathrm{Y})$ & 1 & $*$ & $* *$ & $* *$ & $* *$ & $* *$ & $* *$ \\
\hline Planting date (PD) & 1 & $* *$ & $* *$ & $* *$ & $* *$ & $* *$ & ** \\
\hline Density (D) & 1 & $* *$ & $* *$ & NS & $* *$ & NS & NS \\
\hline Cultivar (C) & 6 & $* *$ & $* *$ & $* *$ & $* *$ & $* *$ & $* *$ \\
\hline \multicolumn{8}{|l|}{ Interactions } \\
\hline $\mathrm{PD} \times \mathrm{C}$ & 6 & $* *$ & $* *$ & $* *$ & $* *$ & $*$ & ** \\
\hline $\mathrm{PD} \times \mathrm{Y}$ & 1 & NS & NS & $* *$ & $*$ & * & $* *$ \\
\hline $\mathrm{PD} \times \mathrm{D}$ & 1 & $*$ & $*$ & NS & NS & NS & NS \\
\hline $\mathrm{D} \times \mathrm{Y}$ & 1 & NS & * & NS & $*$ & $*$ & ** \\
\hline $\mathrm{Y} \times \mathrm{PD} \times \mathrm{D}$ & 1 & $* *$ & * & NS & * & $*$ & NS \\
\hline $\mathrm{C} \times \mathrm{PD} \times \mathrm{D}$ & 6 & $* *$ & $*$ & $*$ & $*$ & $*$ & $*$ \\
\hline $\mathrm{Y} \times \mathrm{C} \times \mathrm{PD} \times \mathrm{D}$ & 6 & NS & NS & NS & NS & NS & NS \\
\hline
\end{tabular}

s,*,***Nonsignificant or significant at $P<0.05$ or 0.01 , respectively.

'Dulce', 'Tam Sweet2', and 'TAM Jalapeño1' after $88 \mathrm{~d}$. In the second planting of 2000, 'Pace103', 'Pace105', 'Dulce', and 'Delicias' were harvested after $82 \mathrm{~d}$; 'Tam Sweet2' after $84 \mathrm{~d}$; and 'Pace108' and 'TAM Jalapeño1' after 85 d. In the first planting of 2001, 'Pace 105 ' and 'Pace108' were harvested after $88 \mathrm{~d}$; 'Delicias' after 89 d; 'Dulce' and 'Pace103' after $90 \mathrm{~d}$; and 'Tam Sweet2' and 'TAM Jalapeño1' after $91 \mathrm{~d}$. In the second planting of 2001, 'Pace105' was harvested after $81 \mathrm{~d}$; 'Pace108' and 'Delicias' after $82 \mathrm{~d}$; 'Pace 103' after $83 \mathrm{~d}$; and 'Dulce', 'Tam Sweet2', and 'TAM Jalapeño1' after $84 \mathrm{~d}$.

All marketable and cull yield components were affected by the main effects variables of 
year, planting date, and cultivar, while only numbers of marketable and cull fruit and marketable yield were affected by density; and there were several significant interactions of those variables (Table 1). Most significant interactions included two main effect variables. However, two significant interactions comprised three factors that affected the data. They were: Year $\times$ Planting date $\times$ Density and Cultivar $\times$ Planting date $\times$ Density. Since these were of a higher order than the other interactions, only the data contained in them are presented (Table 2).

In the Year $\times$ Planting date $\times$ Density interaction, numbers of marketable fruit and marketable yield were generally higher for plants established at the higher density. The exception was for the later planting in 2000 at the lower plant density, where a greater number of marketable fruit was produced. This did not translate into a higher yield. In 2000, the number and yield of cull fruit produced on plants in the higher density were greater for the first planting than for the second one. In 2001 , this same pattern was found for numbers of cull fruit, but not for cull yield, which were not different.

The ANOVA indicated differences in average marketable and cull fruit weights between planting dates. In 2000, across cultivars and densities the average marketable fruit weights were 30.5 and $15.5 \mathrm{~g}$, respectively, for the first and second plantings. In 2001, across cultivars and densities the average marketable fruit weights were 26.4 and $22.6 \mathrm{~g}$, respectively, for the first and second plantings. Reductions in average marketable fruit weight between the planting dates did not appear to be due, in the most part, to large differences in fruit size. The lower fruit weights may be due to reduction in wall thickness, although this was not confirmed by observation. In both years, average cull fruit weight for individual cultivars was a third, or less, of that for marketable fruit. In most cases, this was due to small fruit size.

In the Cultivar $\times$ Planting date $\times$ Density interaction, numbers of marketable fruit and marketable yield of cultivars were generally higher when the density was higher regardless of planting date. For numbers of marketable fruit the exceptions were for 'Pace103' and 'TAM Sweet2', where yields were greater at the later planting and the lower density at the earlier planting date. For 'Dulce', 'Pace103', and 'Pace108' there were no differences between densities from the later planting. Where significance was found, the average marketable fruit weight was higher for 'Pace105' and 'TAM Jalapeño1' at the lower density and earlier planting date. Where significance was found, the average cull fruit weight was higher for 'Dulce' and 'Pace108' at the lower density and earlier planting date, and for 'Pace103' at the higher density and later planting date.

In both years the ANOVA table indicated that marketable yields from planting dates were different (Table 1). In 2000, yields across cultivars and densities were 8.45 and $4.6 \mathrm{Mg} \cdot \mathrm{ha}^{-1}$ for the first and second planting dates, respectively. In 2001, yields across cultivars and densities were 10.75 and $5.2 \mathrm{Mg} \cdot \mathrm{ha}^{-1}$ for the first and
Table 2. Effects of interactions on marketable and cull yield components of pungent and nonpungent jalapeño peppers cultivars transplanted at two planting dates and two densities in 2000 and 2001.

\begin{tabular}{|c|c|c|c|c|c|c|c|c|}
\hline \multirow[b]{2}{*}{ Source } & & & \multicolumn{3}{|c|}{ Marketable } & \multicolumn{3}{|c|}{ Cull } \\
\hline & & & $\begin{array}{c}\text { No. } \\
\text { (1000s/ha) }\end{array}$ & 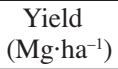 & $\begin{array}{c}\text { Avg fruit } \\
\text { wt }(\mathrm{g})\end{array}$ & $\begin{array}{c}\text { No. } \\
\text { (1000s/ha) }\end{array}$ & 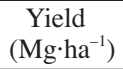 & $\begin{array}{c}\text { Avg fruit } \\
\text { wt (g) }\end{array}$ \\
\hline \multicolumn{9}{|c|}{ Year $\times$ Planting date $^{\mathrm{z}} \times$ Density $^{\mathrm{y}}$} \\
\hline \multirow[t]{5}{*}{2000} & 1 & 1 & 215.1 & 6.5 & 31.1 & 91.0 & 0.9 & 9.0 \\
\hline & & 2 & $\begin{array}{c}354.7 \\
*\end{array}$ & $\begin{array}{c}10.4 \\
*\end{array}$ & $\begin{array}{l}29.8 \\
\text { NS }\end{array}$ & $\begin{array}{c}133.2 \\
* *\end{array}$ & $\begin{array}{c}1.6 \\
*\end{array}$ & $\begin{array}{c}10.0 \\
\text { NS }\end{array}$ \\
\hline & 2 & 1 & 331.1 & 5.0 & 16.0 & 356.7 & 3.2 & 3.4 \\
\hline & & 2 & 287.6 & 4.2 & 15.0 & 194.2 & 2.3 & 3.3 \\
\hline & & & $*$ & NS & NS & $* *$ & $*$ & NS \\
\hline \multirow[t]{6}{*}{2001} & 1 & 1 & 336.5 & 9.1 & 26.7 & 95.9 & 1.4 & 15.2 \\
\hline & & 2 & 452.0 & 12.4 & 26.1 & 111.6 & 1.6 & 13.9 \\
\hline & & & $* *$ & $* *$ & NS & $*$ & NS & NS \\
\hline & 2 & 1 & 184.7 & 4.6 & 23.0 & 170.0 & 1.3 & 9.6 \\
\hline & & 2 & 259.2 & 5.8 & 22.2 & 111.1 & 1.1 & 9.5 \\
\hline & & & $* *$ & $*$ & NS & $*$ & NS & NS \\
\hline
\end{tabular}

$\underline{\text { Cultivar } \times \text { Planting date } \times \text { Density }}$

Delicias $^{\mathrm{X}}$

\begin{tabular}{|c|c|c|c|c|c|c|c|c|}
\hline \multicolumn{9}{|c|}{7507} \\
\hline & 1 & 1 & 352.7 & 7.3 & 19.4 & 142.7 & 1.5 & 9.0 \\
\hline & & 2 & 462.9 & 9.8 & 21.2 & 147.4 & 1.6 & 9.3 \\
\hline & & & $* *$ & $*$ & NS & NS & NS & NS \\
\hline & 2 & 1 & 206.9 & 3.1 & 14.5 & 460.4 & 1.8 & 5.6 \\
\hline & & 2 & 335.0 & 4.7 & 12.7 & 418.1 & 1.6 & 5.0 \\
\hline & & & $* *$ & $*$ & & NS & NS & NS \\
\hline \multirow[t]{6}{*}{ Dulce } & 1 & 1 & 203.1 & 5.7 & 5.6 & 37.6 & 0.5 & 16.9 \\
\hline & & 2 & 354.0 & 10.9 & 27.7 & 90.7 & 1.4 & 11.9 \\
\hline & & & $* *$ & $* *$ & NS & $* *$ & $*$ & * \\
\hline & 2 & 1 & 288.0 & 5.4 & 17.3 & 108.0 & 1.8 & 5.7 \\
\hline & & 2 & 311.3 & 5.7 & 16.4 & 234.2 & 1.2 & 5.6 \\
\hline & & & $*$ & NS & NS & $* *$ & $*$ & NS \\
\hline \multirow[t]{6}{*}{ Pace103 } & 1 & 1 & 234.5 & 9.5 & 38.0 & 72.1 & 1.2 & 14.2 \\
\hline & & 2 & 361.6 & 14.3 & 35.8 & 92.3 & 1.6 & 16.1 \\
\hline & & & $* *$ & $* *$ & NS & $*$ & NS & $*$ \\
\hline & 2 & 1 & 200.0 & 5.2 & 28.8 & 254.4 & 1.1 & 8.8 \\
\hline & & 2 & 180.7 & 5.6 & 25.5 & 173.3 & 2.0 & 8.6 \\
\hline & & & $*$ & NS & NS & $* *$ & NS & NS \\
\hline \multirow[t]{6}{*}{ Pace105 } & 1 & 1 & 240.5 & 9.9 & 38.1 & 100.3 & 1.6 & 13.0 \\
\hline & & 2 & 340.8 & 12.1 & 33.8 & 104.3 & 1.5 & 14.4 \\
\hline & & & $* *$ & $* *$ & $*$ & NS & NS & NS \\
\hline & 2 & 1 & 180.7 & 6.3 & 25.2 & 445.0 & 2.0 & 7.3 \\
\hline & & 2 & 213.1 & 4.9 & 28.3 & 203.8 & 1.7 & 8.9 \\
\hline & & & $*$ & $*$ & NS & $* *$ & NS & NS \\
\hline \multirow{6}{*}{ Pace108 } & 1 & 1 & 200.9 & 8.0 & 39.2 & 71.6 & 1.2 & 14.8 \\
\hline & & 2 & 324.7 & 13.6 & 39.2 & 114.9 & 2.0 & 15.8 \\
\hline & & & $* *$ & $* *$ & NS & $* *$ & $*$ & NS \\
\hline & 2 & 1 & 157.6 & 4.9 & 25.7 & 257.7 & 2.1 & 10.4 \\
\hline & & 2 & 182.7 & 4.9 & 24.9 & 246.6 & 1.5 & 8.6 \\
\hline & & & $*$ & NS & NS & NS & $*$ & $*$ \\
\hline \multicolumn{9}{|c|}{ TAM Jalapeño1 } \\
\hline & 1 & 1 & 412.9 & 7.3 & 18.1 & 146.9 & 1.1 & 6.5 \\
\hline & & 2 & 581.7 & 8.8 & 13.7 & 174.7 & 1.5 & 7.0 \\
\hline & & & $*$ & NS & $*$ & $*$ & NS & NS \\
\hline & 2 & 1 & 171.2 & 2.4 & 12.6 & 402.8 & 1.3 & 4.0 \\
\hline & & 2 & 299.4 & 3.7 & 11.7 & 418.0 & 1.4 & 4.1 \\
\hline & & & $* *$ & $*$ & NS & NS & NS & NS \\
\hline \multicolumn{9}{|c|}{ TAM Sweet2 } \\
\hline & 1 & 1 & 285.7 & 7.2 & 23.8 & 83.1 & 1.0 & 10.2 \\
\hline & & 2 & 397.9 & 10.2 & 24.2 & 132.4 & 1.7 & 9.4 \\
\hline & & & $* *$ & $* *$ & NS & $* *$ & NS & NS \\
\hline & 2 & 1 & 645.1 & 7.4 & 12.4 & 101.8 & 0.5 & 3.7 \\
\hline & & 2 & 372.2 & 4.0 & 10.6 & 54.9 & 0.3 & 3.9 \\
\hline & & & $* *$ & $* *$ & NS & $* *$ & NS & NS \\
\hline
\end{tabular}

${ }^{2}$ In 2000 planting date $1=15$ Apr. and planting date $2=17$ June. In 2001 planting date $1=16$ Apr. and planting date $2=8$ June.

${ }^{\mathrm{y}}$ Density $1=24,216$ plants/ha and was derived from establishing one plant at each transplant site. Density $2=48,432$ plants/ha and was derived from establishing two plants at each transplant site.

${ }^{\mathrm{x}}$ Cultivars are listed alphabetically.

Ns, ,***Nonsignificant or significant at $P<0.05$ or 0.01 , respectively. 
second planting dates, respectively. For the first planting, the numbers of marketable fruit were either similar to, or smaller than, those for the second plantings. Since there were no reductions in numbers from the first to second plantings, the differences in marketable yield between planting dates appears to be due to production of lighter marketable fruit. The period of the second planting date was somewhat hotter than the period for the first planting date. This may have contributed to altered maturation, and smaller fruit, as is the case for bell pepper (Rylski, 1973).

Many of the cultivars appear to have the potential to produce acceptable yields from a mid-June planting, but use of more than one plant at a transplant site may not be advisable. Russo (1996) found that when the pungent jalapeño 'Mitla' and the long, yellow wax pepper 'Sweet Banana \#504' were transplanted in mid-July at this same location, yields were higher than for those transplanted in mid-April. For that experiment, fruit were likely forming as temperatures were moderating. The 'TAM Sweet2', 'Delicias', and the Pace cultivars may also respond in the same manner, since the first two produce fruit roughly equivalent in size to 'Mitla', and the Pace cultivars produce fruit that are roughly equivalent in size to that of a Banana-type pepper.

For bell pepper, for one planting date and location in Florida (Stofella and Bryan, 1988), increasing the number of plants at sites in rows from one to two increased yields about $10 \%$. For the pepper types in this study the higher plant density, achieved by the use of two plants at a transplant site, improved marketable yields by more than $25 \%$ in both years of the study for the earlier planting date. If the cost of additional seed, and the likely need to thin during seedling production, is significantly less than the added income from increased yield, this cultural method would be desirable for early transplanted nonpungent jalapeño peppers.

\section{Literature Cited}

Andrews, J. 1995. Peppers: The domesticated Capsicums. 2nd ed. Univ. Texas Press, Austin.

Cochran, H.L. 1932. Factors affecting flowering and fruit setting in the pepper. Proc. Amer. Soc. Hort. Sci. 29:434-437.

Decoteau, D.R. and H.A.H. Graham. 1994. Plant spatial arrangement affects growth, yield, and pod distribution of cayenne peppers. HortScience 29:149-151.

Deli, J. and H. Tiessen. 1969. Interaction of temperature and light intensity on flowering of Capsicum frutescens var. grossum cv. California Wonder. J. Amer. Soc. Hort. Sci. 40:493-497.

Dorland, R.E. and F.W. Went. 1947. Plant growth and controlled conditions. VIII. Growth and fruiting of the chili pepper (Capsicum annuиm). Amer. J. Bot. 34:393-401.
Johnson, C.D. and D.R. Decoteau. 1996. Nitrogen fertility affects Jalapeño pepper plant growth, pod yield, and pungency. HortScience 31: 1119-1123.

Jolliffe, P.A. and M.M. Gaye. 1995. Dynamics of growth and yield component responses of bell peppers (Capsicum annuит L.) to row covers and population density. Scientia Hort. 69:153-164.

Kahn, B.A., J.R. Cooksey, and J.E. Motes. 1997. Within-row spacing effects on traits of importance to mechanical harvest in paprika-type peppers. Scientia Hort. 69:31-39.

Leskovar, D.T. and A.K. Boales. 1995. Plant establishment systems affect yield of Jalapeño peppers. Acta Hort. 412:275-280.

Motes, J.E. and W. Roberts. 1994. Fertilizing commercial vegetables. Okla. State Univ. Ext. Facts, No. 6000.

Motsenbocker, C.E. 1996. In-row plant spacing affects growth and yield of pepperoncini pepper. HortScience 31:198-200.

Motsenbocker, C.E., J.B. Buckley, W.A. Mulkey, and J.E. Boudreaux. 1997. Mechanical harvest of Jalapeno pepper influenced by plant spacing. HortTechnology 7:149-152.

Russo, V.M. 1996. Planting date, fertilizer rate, and harvest timing affect yield of Jalapeño and Banana peppers. HortScience 31:1124-1125.

Rylski, I. 1973. Effect of night temperature on shape and size of sweet pepper (Capsicum aпnиит L.). J. Amer. Soc. Hort. Sci. 98:149-152.

Stoffella, P.J. and H.H. Bryan. 1988. Plant population influences growth and yields of bell pepper. J. Amer. Soc. Hort. Sci. 113:835-839. 